\title{
Text-image relationships in contemporary fairy tales
}

\author{
Victoria Yefymenko \\ Taras Shevchenko National University of Kyiv, Ukraine
}

\begin{abstract}
The article analyzes relations between the text and the image as two different semiotic modes in the framework of multimodal studies. Key theoretical approaches to this issue are outlined. Visual and verbal narratives are examined at three levels: ideational, interpersonal and textual. The ideational meaning system comprises actions, characters and circumstances. The interpersonal system covers a wide range of issues connected with interaction between the reader and the characters. The textual meaning is realized by giving prominence to certain objects in the image or the text. Logico-semantic relations of elaboration, enhancement and extension are revealed. Elaboration is characterized by clarification and exemplification, the image may be more general than the text, and vice versa. Enhancement relations include various circumstances (temporal, spatial, causal), besides, both the text and the image may enhance each other. Extension adds new, semantically unrelated information and offers alternative ways of story unfolding. The research is based on contemporary picture books (J. Scieszka, L. Anholt, F. French, R. Munsch) and illustrated fairy tales (E. Delessert, B. Ensor) and directed at revealing various types of text-image relations.
\end{abstract}

Keywords: text, image, contemporary fairy tale, multimodal discourse analysis

\section{Introduction}

One of the recent tendencies in linguistics is the development of multimodal research, aimed at the analysis of various semiotic systems that create meaning. Relations between the text and the image as two different semiotic modes are one of the areas of multimodal studies. Traditionally texts and images were analyzed by separate branches of science with their own approaches and methods of research. However, within multimodal studies the text and the image are considered as a combination of interrelated modes. Correlations between verbal and visual elements have been examined in the works of such scholars as R. Barthes, 1977; B. Spillner, 1982; M. Nikolajeva, C. Scott, 2006; D. E. Agosto, 1999; K. Schriver, 1997; H. Stöckl, 2009; R. Martinec and A.Salway, 2005; G. Kress and T. van Leeuwen, 1996; T. D. Royce, 2007; J. Bateman, 2014 and others.

The aim of this paper is to analyze relationships between verbal and visual fragments in contemporary fairy tale retellings. One of the tendencies of the end of the 20th - the beginning 
of 21 st century was proliferation of retellings of classic fairy tales. They differ from traditional fairy tales in a number of ways: they have contemporary setting, first-person narrative (they are often told by the protagonist or the antagonist of traditional fairy tales), characters' psychological development and revision of traditional gender roles. In our analysis we will focus on contemporary picture books and illustrated fairy tales.

Picture books occupy a separate genre niche due to the importance of visual narrative in them. Well-known researchers of picture books M. Nikolajeva and C. Scott (2001) pointed out that "the unique character of picture books as an art form is based on the combination of two levels of communication, the visual and the verbal" (p. 1). They singled out the following types of picture books: symmetrical picture books (with two mutually redundant narratives), complementary picture books, in which words and pictures fill each other's gaps, 'expanding' or 'enhancing' picture books, where visual narrative supports verbal narrative, 'counterpointing' picture books with two mutually dependent narratives and 'sylleptic' picture books, containing two or more independent narratives (Nikolajeva \& Scott, 2001, p. 12). The distinctive feature of picture books is the 'dual' nature of their narratives, interdependence of the image and the text, while in illustrated books the text plays the dominant function and illustrations appear at certain points to provide a visual expression of events at these points. Thus, visual narrative has a lot of gaps that are filled by the text.

D. E. Agosto (1999) in his analysis of picture books distinguished two main categories: augmentation and contradiction. The first category includes irony, humour, intimation, when visual elements help to interpret the text, fantastic representation (in the case of a realistic text and imaginary visuals) and transformation, where the combination of the text and pictures transforms the meaning of each of them if taken separately. The second group of storytelling strategies, apart from irony and humour, which may belong to both categories, includes disclosure - when the reader is aware of some information unknown to the characters. D. E. Agosto has also pointed out that more than one strategy may be realized by the author simultaneously.

As it has already been mentioned, the text and the image are two different semiotic modes. According to M. A. K. Halliday's systemic-functional linguistics, every semiotic system operates at three levels. First, it represents reality by referring to certain objects and situations (ideational metafunction). Second, each semiotic system establishes some kind of interaction with the recipient (interpersonal metafunction). Finally, it builds a textual structure with coherent components (textual metafunction) (Halliday, 1978). Visual grammar of G. Kress and T. van Leeuwen (1996) finds parallels between the text and the image by examining the latter at the three above-mentioned levels. For instance, at the ideational level, viewers determine which fragment of the world is depicted in the picture, whether it denotes some action, process or is simply a conceptual representation. Correspondingly, images, such as verbal clauses, may have participants, processes and circumstances. At the interpersonal level, pictures can either offer information or demand some action from the reader. G. Kress and T. van Leeuwen in their analysis of reader-character relationships refer to the following visual meaning systems: social distance, attitude (including involvement and power), contact and modality. Social distance is realized by a shot size: whether a character is presented in 'close up', 'mid shot' or 'long shot' (Kress \& van Leeuwen, 1996, p. 124). The degree of involvement depends on the angle from 
which the character is viewed, and the reader has a maximum sense of involvement when characters are presented facing him 'front on'. Vertical angle is the realization of power: what the reader/viewer looks up to has power, and, on the contrary, everything he looks down on is considered to be weak (Kress \& van Leeuwen, 1996, p. 140). Distance between viewers and images varies: from focus on details to a generalized picture. The same is true about the degree of reality, as images can be naturalistic or schematic (Kress \& van Leeuwen, 1996, p. 121). At the textual level, viewers receive information according to the value of some of the elements, as is the case of the centre/ margin structure, where the main element is positioned in the centre and subsidiary elements on the margins. Objects placed close to each other may be semantically connected. Besides, such visual devices as colour, shape, lighting give prominence to key semantic elements.

C. Painter, J. R. Martin and L. Unsworth in their book Reading Visual Narratives (2012) has reinterpreted and elaborated G. Kress and T. van Leeuwen visual grammar. In particular, at the interpersonal level, apart from social distance, involvement and power, they examined such meaning systems as focalization, pathos, proximity, orientation, ambience, affect and graduation. Focalization is connected with the direction of the character's gaze and can be mediated, when the reader's gaze is aligned with the character's and the process of viewing happens through the eyes of the character, and unmediated (Painter, Martin \& Unsworth, 2012, p. 21). Pathos is determined by the drawing style of the picture, which can be minimalist, generic or naturalistic, which, in turn, determines the degree of engagement and empathy from the reader. Affect includes emotions depicted in facial features and bodily stance of characters. Such systems as proximity and orientation go in parallel with those of social distance and involvement, but take into account the relations of characters to each other: the former determines the degree of closeness of characters to each other, the latter - the bodily orientations of characters to each other (Painter, Martin \& Unsworth, 2012, p. 17). Ambience deals with colour choices and is further divided into the systems of vibrancy (depends on the depth of saturation), warmth (contrast between warmer and cooler colours) and familiarity, which is realized by the amount of colour differentiation in the image (Painter, Martin \& Unsworth, 2012, pp. 37-38). Finally, the graduation system includes scaling and quantification (e.g. repetition of elements, exaggerated size).

Cohesion introduced by M. A. K. Halliday and R. Hasan is widely used in the context of text-image relations. T. Royce has further developed the notion of cohesion. According to his model of intermodal complementarity (Royce, 2007), it is necessary to identify visual processes and their visual participants in the visual narrative and find relations between them, verbal processes and participants in the text discourse. Such cohesive relations between textual and visual rendition of a certain episode form intermodal cohesion.

B. Spillner (1982) came up with the idea of priority, and argued that one semiotic mode might determine the meaning communicated by another, and in asymmetric situations one semiotic mode would be primary and the other secondary. Moreover, both the text and the image could take the primary role (Spillner, 1982, p. 92). B. Spillner also distinguished cases when one semiotic system - either texts or images - acquired the functions of the other. For instance, texts may communicate dynamism with the help of typography or be 'shaped' in a certain way to emphasize a particular meaning. Images become dynamic as a result of the so 
called visual vectors - explicit or implicit lines created by visual forms (e.g. direction of movement of characters' arms and legs, their gaze etc.).

K. Schriver (1997) offered his own classification of relations between elements of documents belonging to different semiotic modes, including texts and images: redundant, where the same information is expressed in two modalities; complementary, where the information in one mode complements the information contained in the other mode, but they are equally important; supplementary, where one mode dominates the other; juxtapositional, where the meaning is created as a result of a tension between the information in each mode; stage-setting, where one mode provides a context for the other mode (Schriver, 1997, pp. 412428).

R. Martinec and A. Salway (2005) introduced a detailed classification of text-image relations, which was based on two broad categories: status and logico-semantic relations. Equal status relations envisage that an entire text is related to an entire image and are further divided into two subtypes: independent (when the text and the image do not merge and exist as parallel meaning systems) and complementary (when both the text and the image contribute to the meaning), while unequal status relations exist when part of the text relates to the image or vice versa. Logico-semantic relations are divided into two large groups: expansion and projection. Expansion includes elaboration, extension and enhancement. These notions were first introduced by M.A.K. Halliday (Halliday \& Matthiessen, 2014, p. 460) to explain relations between parts of sentences, but they are suitable to describe text-image relations as well. Elaboration adds further information or exemplifies, and either the text can be more general than the image or vice versa. The former type of relations is called by researchers exposition and the latter - exemplification. Exemplification is often accompanied by lexical cohesion. The second subcategory of expansion, enhancement, specifies information connected with time, place, manner etc. Finally, extension adds new, semantically unrelated information and offers alternative ways of story unfolding (Martinec \& Salway, 2005, p. 358).

T. van Leeuwen analyzed the following relations between visual and verbal elements: elaboration, which included specification (when the image makes the text more specific or vice versa) and explanation (the text paraphrases the image or vice versa); and extension, including similarity (the content of the text is similar to the content of the image), contrast (the content of the text contrasts with that of the image) and complement (adding further information) (van Leeuwen, 2005, p. 230).

H. Stöckl, apart from content-related relations between texts and images which included elaboration and extension, considered also spatial-syntactic and rhetorical-logical patterns. In the first case one mode follows the other in a sequence or the text and the image are spatially integrated to be perceived simultaneously as an entity. Rhetorical-logical patterns include three broad types of linkage: coordination (relations between the text and the image are based on likeness, contrast, spatial-temporal contiguity), hierarchy, when one mode governs the other, and coincidental, allusive and meta-communicative connections (Stöckl, 2009, pp. 214-219). 


\section{Text-image relations at the ideational, interpersonal and textual levels}

Our first task is to examine visual and verbal narratives at three levels: ideational, interpersonal and textual. The ideational meaning system comprises actions, characters and circumstances. As it has already been mentioned, actions are visually realized with the help of vectors, which help such static medium as an image to express dynamics. Let's analyze several examples from contemporary fairy tales. The first example is taken from L. Anholt picture book Little Red Riding Wolf:

The Big Bad Girl leapt out of bed, down the stairs, out of the door, into the forest and along the path as fast as her big bad legs would carry her (Anholt, 2002, p. 56).

The illustration accompanying this text fragment depicts a girl who runs as fast as she can, leaving puffs of dust and drops of sweat behind her, all this creates the visual vector of her movement. In this case the image amplifies the text. Verbal realization of the action is carried out by a verb 'to leap' indicating a material process of motion. In the next example from J. Scieszka Little Red Running Shorts the movement is conveyed not only by visual vectors, but also by means of other devices:

Let's go wolf. We're out of here (Scieszka, 1992, p. 22).

The illustration depicts how Little Red Running Shorts and the Wolf go from Jack the narrator, leaving footprints behind them. This track of footprints toward the left side of the page clearly indicates the action of leaving the page. Verbally the action is expressed by the material process verb 'to go'. This picture contains one more action - Jack's talking, indicated by his open mouth and hand gestures, and verbally realized by his reply "Wait. You can't do this." In some fairy tales talking in the visual narrative is rendered by means of speech bubbles and cognition - by thought bubbles. In the corresponding verbal narratives these actions are expressed by verbal and mental process verbs.

Let's examine the depiction of characters in fairy tales in terms of character manifestation, appearance and relations (Painter, Martin \& Unsworth, 2012, p. 64). Character manifestation may be complete or metonymic. For instance, in F. French Snow White in New York on two adjacent pages the reader can see two hands: one with a ring with a skull carrying a cocktail with a poisoned cherry, and the other without any distinctive features. We assume that the first hand belongs to the stepmother and the second - to Snow White. Another example of metonymic character manifestation can be found in L. Anholt's Little Red Riding Wolf, when a large furry paw appears in the doorway, and the text below the picture gives further explanations:

At that precise moment Old Granny Wolf pushed open the door (Anholt, 2002, p. 51).

Other cases of metonymic character manifestation include silhouettes. In the same fairy tale, on the pages dedicated to the description of Snow White's death, a large number of black silhouettes represent crowds of people that stood in the rain and watched Snow White's coffin 
pass by. In B. Ensor's Cinderella the majority of illustrations contain silhouettes of characters. For instance, two symmetrically arranged silhouettes of Cinderella's and prince's heads contain the thoughts of the characters:

Thank goodness she doesn't know that my mother made me take dance classes!

Thank goodness he doesn't know I got a total makeover from my fairy godmother!

(Ensor, 2011, pp. 62-63)

Adjacent arrangement of images invites their comparison, in particular, of thoughts that appear simultaneously in two characters' minds. In J. Scieszka's Little Red Running Shorts there is an illustration with white cut-outs of Little Red Running Shorts and the Wolf indicating their absence from the story. This is an example of non-traditional postmodernist fairy tale, in which the narrator loses control over the characters and the process of book creation and its material character is foregrounded. As a rule, the main characters of fairy tales reappear in the pictures with new descriptive details, in different clothes or accessories. For instance, in R. Munsch's The Paper Bag Princess the main heroine's royal clothes were burnt by a dragon, and she has to wear a paper bag, but it doesn't prevent readers from recognizing her.

Finally, such element of ideational meaning as circumstances deals with the setting of the fairy tale. For instance, time in Snow White in New York is visually indicated by the rising sun and verbally - by the time expression 'in the early morning'. Sometimes visual depiction of time (e.g. moon, lighted windows) has no corresponding verbal specifications. Inter-circumstance options include decontextualization, when the setting is reduced compared to the previous depiction and characters are brought into focus, and recontextualisation, where the setting is increased (Painter, Martin \& Unsworth, 2012, p. 79). In Snow White in New York two conceptual images of Snow White and her stepmother are followed by the description of New York skyscrapers and a bridge with a tiny figure of Snow White and one of her stepmother's bodyguards whom she ordered to shoot the girl in down town. This is an example of recontextualisation. The text fragment contains such place references as 'down town' and 'dark streets'. The setting of two successive images sometimes remains the same, but it may be viewed from a new perspective through zooming in or out. It happens, for instance, during Snow White's performance in the club, when first she is depicted on the stage singing accompanied by seven jazz-men, and, in the following picture, the stage is viewed from the perspective of a newspaper reporter who watches the girl's performance. The place is also specified in the text ('the club').

The interpersonal meaning systems cover a wide range of issues connected with interaction between the reader and the characters. For instance, full page portraits of Snow White in F. French and E. Delessert fairy tales facing the reader 'front on' create a sense of intimacy and involvement between the reader and the character. Besides, they gaze out to meet the reader's gaze, so a direct contact is established between them, while other characters depicted at an oblique angle make the reader more detached from them. If characters don't gaze out to the reader, focalization can be unmediated and mediated. We find examples of mediated focalization in Snow White in New York, when the reader's gaze is aligned with the reporter's as he watches Snow White singing. Verbal focalization is expressed by a mental cognitive verb 'to 
know' referring to the reporter as an internal focalizer. An interesting example can be found in E. Delessert's The Seven Dwarfs. Here visual focalization is mediated, i.e. the reader sees Snow White coming to the room 'over the shoulder' of the dwarfs. At the same time in the text the focalizer is the girl:

Early the next morning when we awoke, the young girl was standing in the kitchen doorway watching us (Delessert, 2001, p. 17).

Verbal focalization is expressed by a verb of perception 'to watch'. R. Munch's The Paper Bag Princess ends with the princess standing with her back to the reader looking at the rising sun. Such mediated visual focalization has no verbal correspondence. Talking about another component of an interpersonal meaning system - pathos, it has to be mentioned that contemporary fairy tales with illustrations depicted in the minimalist style (e.g. L. Anholt's Little Red Riding Wolf or Snow White and the Seven Aliens) make the reader a rather detached observer of the characters, at the same time they add humorous effect. Pictures in generic style from F. French and E. Delessert fairy tales increase the reader's empathy to the depicted characters. Verbally, pathos is realized through characterization.

Colours of illustrations, in particular, their vibrancy, warmth and differentiation, determine the ambience (Painter, Martin \& Unsworth, 2012, p. 36). Pictures in Snow White in New York are characterized by high saturation that creates a sense of vitality, while muted colours of illustrations in The Seven Dwarfs create a more restrained feeling. There is also a contrast between the warmer colours (red, yellow, orange) of pictures depicting Snow White's performance in the club, and cooler blue, brown and black colours of the illustration of her funeral. Such choice of colours reflects the emotional states of the characters. These emotions find their verbal realization in the text:

All New York was shocked by the death of beautiful Snow White (French, 1989, p. 25).

Some picture books, for instance, those of L. Anholt, are entirely in black and white, and their simple line drawings have no ambience. Others use a restricted palette. For instance, pictures in black, white and red in Rood Rood Roodkapje by E. van de Vendel signal removal from reality and isolation of the main character. Visual graduation in Snow White in New York is realized by a double-page spread divided into two unequal parts, one of which features the stepmother putting a poisoned cherry in a cocktail and the other - a large number of guests at the grand party given by the stepmother.

One of the key elements of textual meaning is framing. Illustrations in F. French's fairy tale are unbound, as they extend to the page edge, apart from two large portraits of Snow White and the stepmother, which are framed by admirers and bodyguards respectively. Though both frames are done in dark hues, the one surrounding Snow White's portrait consists of smiling faces of men, two of whom hold bouquets of red flowers, while the frame surrounding the stepmother's portrait is formed of sulky and gloomy faces. These frames reinforce the ambience and highlight the contrast between the two main heroines. All the images in this book are 
contextualized (there is no white space background), whereas illustrations in E. Delessert's book are bound with a margin of white space enclosing them.

In some fairy tales mirrors become 'frames within the frame'. Sometimes mirror frames have distinct masculine traits, as they contain men's faces and may be associated with patriarchal masculine voices (Joosen, 2011, p. 230). Frames in some contemporary fairy tales undergo transformations as their plot unfolds. For example, in P. Heins's Snow White the frame of the huge mirror that belonged to the stepmother, consisted of skulls, heads and bodies of trolls and devils, including the queen's own head and a smiling she-devil parodying a crucified Jesus Christ. When, on the final page of the book, the image of the mirror appears again, a remarkable transformation takes place: the evil faces are replaced with more pleasant and mostly female ones and the skull on top of the frame turns into the head of a beautiful woman. But several dark figures are still hiding in the shadow. The modified frame has a symbolic meaning: the future which awaits Snow White may be much more pleasant than her stepmother's life, but still the danger of repeating her fate remains.

The integration of the image and the verbiage in the layout of contemporary fairy tales takes several forms. First of all, characters' words may appear in speech bubbles, as is the case in L. Anholt Little Red Riding Wolf. It is an example of projected layout (Painter, Martin \& Unsworth, 2012, p. 99). Expanded layout is characteristic of F. French's Snow White in New York, where the verbiage appears on the image, thus creating the strongest fusion between words and images. In A. Ikhlef's picture book Mon Chaperon Rouge there is a more subtle integration of the image and the verbiage: in one of the illustrations, the text appears on the page of a large book within the book, which acts as a cradle for a little girl in red. Textual meaning is also created with the help of the focus. If we analyze the pictures from F. French's fairy tale, the majority of double-page spreads are polarized: some of them are mirroring (e.g. portraits of Snow White and her stepmother mirror one another), there are also balanced (when both poles of composition are filled) and unbalanced (e.g. when one pole contains a large picture of the stepmother during her wedding, and the other - a small lonely figure of Snow White) focus groups.

\section{Logico-semantic relations of elaboration, extension and enhancement}

Let's analyze in more detail the text-image relations of elaboration, extension and enhancement. Elaboration takes place when the same participants, processes and circumstances are depicted in the picture and mentioned in the text. Elaboration is further subdivided into exposition, specification and exemplification. Cases of exposition, when the whole text fragment corresponds to the image, are more characteristic of picture books with small text fragments on a page. In the case of specification, either the image makes the text more specific or, vice versa, the text makes the image more specific. Let's consider the following example: 
This example is taken from a contemporary fairy tale by F. French Snow White in New York. We see how the illustration specifies the text: the coffin is depicted in the black hearse and Snow White is lying in the coffin in a pink dress. The second example also refers to the funeral of Snow White, but other details are highlighted:

We tied her coffin between two horses and rode with the hunters to the castle (Delessert, 2001, p. 28).

Here we see that the coffin is carried by two horses, and dwarfs and hunters walk behind the coffin through the forest. It is also an example of mediated focalization, as the whole funeral procession is observed from behind the backs of two forest animals.

Text-image relations of specification often provide more information connected with the character's appearance or clothes. For instance, in F. French's Snow White in New York after mentioning in the text about the second marriage of Snow White's father there is a large picture of the girl's stepmother. It is done in a generic depiction style, demonstrating green iris of the woman's eyes, eye-lashes and a beauty spot on her right cheek. According to C. Painter, J. R. Martin and L. Unsworth (2012), generic texts invite more empathy on the part of the reader (p. 33). Another illustration from T. Ungerer's fairy tale Little Red Riding Hood depicts the wolf wearing magnificent clothes, a wide brim hat with a feather and a cross-shaped medal. Probably, such imposing appearance makes the main heroine address the wolf as 'Your Excellency', 'noble Prince', and the wolf, in his turn, asks to be called 'Duke'.

The following two text extracts and illustrations that accompany them are examples of exemplification:

The Big Bad Girl was just about as BIG and BAD as a girl can be, and all the woodland animals were afraid of her (Anholt, 2002, p. 4).

She shouted rude things at any little animal who passed by (Anholt, 2002, p. 6).

While in the text all the woodland animals are mentioned, the first illustration makes this general reference more concrete by depicting a squirrel, a hedgehog, a badger, several hares and even birds that disperse, seized by fear. In the second example the textual element (any little animal) is specified not only by the illustration, where a family of hares is depicted, but also by another verbal fragment, contained in a speech bubble (Come on, Big Ears. Hop to it!). As we can see, hyponyms are widely used in exemplification.

In the next example the deictic phrase 'this one' is specified:

"Please, my dear," he begged, “wear this one for me.” (Anholt, 2002, p. 16)

Only by looking at the illustration we understand that Big Bad Girl's father asks her to wear a palm-tree like hat. According to R. Martinec and A. Salway (2005), such cases of deixis belong to unequal status, when the text is subordinate to the image (p. 351). 
As previously mentioned, enhancement offers information connected with time, place, manner, reason, purpose etc. In the following example the setting of the illustration is clarified with the help of the text:

Once upon a time in New York there was a poor little rich girl called Snow White (French, 1989, p. 4).

From the text, the reader understands that the city depicted in the picture is New York and not any other city. In the next example, the opposite process takes place - the image enhances the text:

Snow White wandered the streets all night, tired and hungry. In the early morning she heard music coming from an open door. She went inside (French, 1989, p. 9).

The illustration contains the sign 'Blue Diamond Club' and the depiction of musicians, so the illustration specifies the place which Snow White entered. Enhancement may occur without mentioning the name of the place in the text or in the picture:

Of course, he could not bring himself to cut off that precious snubby nose, so he quickly modeled a false one out of some pink Plasticine which he always carried in his pocket (Anholt, 2002, p. 27).

The picture which accompanies this text fragment depicts Snow White's father in a café making a nose out of pink Plasticine which he is going to give to the girl's stepmother as a proof of her death (a parody to Snow White's heart that the stepmother ordered to bring her in the classical fairy tale). The illustration demonstrates the place which is not mentioned in the text. The text enhances not only spatial but also temporal parameters of the image:

But the Big Bad Girl had no choice. She pulled the ghastly nightcap right down to her eyes and climbed into the bed, just as Little Red Riding Wolf came running up the stairs, skippetyskip (Anholt, 2002, p. 47).

The girl in the picture is lying in bed, one of her feet in boots peeping out of the blanket, and from the text it becomes clear that she got into bed when the wolf was climbing the stairs. Temporal enhancement in this example refers to the same time in textual and visual fragments. There are also cases of different temporal relations which denote events that happened earlier or later.

In the following example verbal and visual components are connected by manner:

And the red riding hat was useful ... when they had an especially heavy load (Anholt, 2002, p. 63). 
It is not clear from the text in which way the hat is useful, but the illustration enhances the text by depicting the wolf who uses the red hat to carry wood. In the next example, it is not the image which enhances the text, but the text which enhances the image:

And so, Snow White's father led his beautiful daughter far into the wild and dangerous city. With tears streaming down his face, he bought her an all-day bus pass and kissed his sweet daughter goodbye (Anholt, 2002, p. 26).

The picture depicts a bus taking Snow White away, and her depressed father who walks away. The picture is enhanced as a result of using, in the text, the construction 'with +- ing form' (With tears streaming down his face) indicating manner. Causal relations exist between the following text fragment from Snow White in New York by F. French and its accompanying image:

All the papers said that Snow White's stepmother was the classiest dame in New York. But no one knew that she was the Queen of the Underworld (French, 1989, p. 6).

In the picture we see the stepmother with a pistol in her hand, who has just fired, but the target is invisible to the reader. The described situation proves that the stepmother belongs to the underworld.

Finally, extension is the third type of relations between the image and the text, when semantically unrelated information is added. Let's look at the following two examples:

Little Wolfie was the sweetest, fluffiest, politest little cub you could ever hope to meet. He would run along the path, skippety-skip, carrying a basket of freshly baked goodies for Old Granny Wolf, singing all the time ... (Anholt, 2002, p. 10).

Snow White and the reporter fell in love. They had a big society wedding, and the next day cruised off on a glorious honeymoon together (French, 1989, p. 30).

In the first example such animals as deer, hares, a badger, a squirrel and even a snail listen to the wolf's song, but no listeners at all are mentioned in the text (unlike the case of elaboration in the same picture book, when a generic noun 'animals' was specified). As for the second example, we can see the stepmother accompanied by two men near the police car. Thus, the story extends and the reader finds out about the stepmother's arrest, though this information is missing in the text fragment. In both of the above-mentioned examples visual fragments extend verbal ones, but in the next example the opposite process takes place:

But Old Granny Wolf was out chopping wood in the forest (Anholt, 2002, p. 43).

We see a room without anybody inside, and the text extends the image explaining where exactly the granny is at the moment. Extension relations may include elements of contrast, if the content of the text contrasts with the content of the image, as in the following example: 
As the days passed, Snow White made friends with King Henry, gathered eggs and mushrooms and even tidied the house (Delessert, 2001, p. 22).

The picture depicts the courtyard with hens, a duck, a pig (King Henry) and Snow White taking water from the well, but there are no indications of processes mentioned in the text. In some cases relations of enhancement and extension are combined:

Then, the Mean Queen would scream with laughter and march around the house croaking her ancient songs ... (Anholt, 2002, p. 15).

The reader can see the stepmother 'playing the broom' while mice are listening to her. Enhancement of manner adds a humorous effect to the fairy tale. Depiction of mice is an example of extension, as in the text there is no mentioning of any kind of audience. Besides, the dynamics of the action is rendered by depicting the stepmother in several (namely four) different poses, which creates the effect of being in constant movement.

To sum up, there are various approaches to the analysis of correlations between visual and verbal fragments within the multimodal studies framework. Both the text and the image may be analyzed at the ideational, interpersonal and textual levels. The ideational meaning system comprises actions, characters and circumstances. Actions are visually realized with the help of vectors, speech and thought bubbles and verbally - by material, verbal and mental process verbs. Depiction of characters in fairy tales is realized in terms of character manifestation, appearance and relations. Character manifestation may be complete or metonymic (parts of the body or silhouettes). Elements of ideational meaning, such as circumstances, deal with the setting of the fairy tale, which may be reduced, increased or viewed from a different perspective.

The interpersonal meaning system covers a wide range of issues connected with the interaction between the reader and the characters. It is visually realized by means of unmediated and mediated focalization, various depiction styles, ambiance and verbally - by verbs of perception, characterization, emotion and evaluative language. The textual meaning in contemporary fairy tales is realized through framing, various types of integration of the image and the verbiage, and focus.

Cohesive ties that exist between verbal and visual elements create intermodal cohesion at the level of processes, participants and circumstances. Image-text logico-semantic relations found in contemporary fairy tales, include elaboration, enhancement and extension. Besides, the text can be more general than the image, or vice versa. There are cases when an entire text is related to an entire image (equal status), or when a part of the text or the image relates to the image or the text respectively (unequal status). Further research of text-image relations may include the comparative analysis of correlations between the text and the image in comics, as well as the multimodal analysis of such transmedial phenomena as digital narratives, computer games, films, cartoons. 


\section{References}

\section{Primary sources}

Anholt, L. (2002). Little red riding wolf. London: Orchard Books.

Anholt, L. (2002). Snow White and the seven aliens. London: Orchard Books.

Delessert, E. (2001). The Seven dwarfs. Mankato: Creative Editions.

Ensor, B. (2011). Cinderella (as if you didn't already know the story). New York: Yearling Book.

French, F. (1989). Snow White in New York. Oxford: Oxford University Press.

Heins, P. (1979). Snow White. New York: Little, Brown Books for Young Readers.

Ikhlef, A., \& Gauthier, A. (1998). Mon Chaperon Rouge. Paris: Éditions du Seuil.

Munsch, R. (2005). The paper bag princess. New York: Annick Press Ltd.

Scieszka, J. (1992). The stinky cheese man and other fairy stupid tales. New York: Viking.

Ungerer, T. (1993). Little Red Riding Hood. In J. Zipes (Ed.), The trials and tribulations of little Red Riding Hood (pp. 261-264). New York: Routledge.

Vendel, E. van de. (2003). Rood rood Roodkapje. Wielsbeke: Uitgeverij De Eenhoorn.

\section{Critical sources}

Agosto, D.E. (1999). One and inseparable: Interdependent storytelling in picture storybooks. Children's Literature in Education, 30(4), 267-280.

Barthes, R. (1977). Image, music, text. Waukegan: Fontana Press.

Bateman, J. (2014). Text and image: A critical introduction to the visual/verbal divide. London, New York: Routledge.

Halliday, M.A.K. (1978). Language as social semiotic. London: Edward Arnold.

Halliday, M.A.K., \& Matthiessen, C. (2014). Halliday's introduction to functional grammar (4th ed.). New York: Routledge.

Joosen, V. (2011). Critical and creative perspectives on fairy tales. Detroit: Wayne State University Press.

Kress, G., \& van Leeuwen, T. (1996). Reading images: The grammar of visual design. London: Routledge.

Leeuwen, T. van (2005). Introducing social semiotics. London: Routledge.

Martinec, R., \& Salway, A. (2005). A system for image-text relations in new (and old) media. Visual communication, 4(3), 337-371.

Nikolajeva, M., \& Scott, C. (2006). How picturebooks work. New York: Routledge.

Painter, C., Martin, J. R., \& Unsworth, L. (2012). Reading visual narratives: Image analysis in children's picture books. Sheffield: Equinox.

Royce, T. D., \& Bowcher, W. L. (Eds.). (2007). New directions in the analysis of multimodal discourse. Mahwah: Lawrence Erlbaum Associates.

Schriver, K. (1997). Dynamics in document design: Creating text for readers. Hoboken: Wiley.

Spillner, B. (1982). Stilanalyse semiotisch komplexer texte. Kodikas/Code. Ars Semeiotica, 4/5(1), 91-106.

Stöckl, H. (2009). The language-image-text - Theoretical and analytical inroads into semiotic complexity. Arbeiten aus Anglistik und Amerikanistik, 34, 203-226. 